\title{
Research Progress on Cloning and Mechanism of Rice Lesion Mimic Genes
}

Qian Jingya $^{1}$ Liu Fen $^{1}$ Qu Cheng ${ }^{1,2 \square}$ Wang Yue ${ }^{1 \square}$

1 College of Agronomy, Hunan Agricultural University, Changsha, 410128, China

2 Hunan Biological Electromechanical Polytechnic, Changsha, 410127, China

D Corresponding author email: wangyue@hunau.edu.cn; qucheng1028@163.com

Rice Genomics and Genetics, 2020, Vol.11, No.2 doi: 10.5376/rgg.2020.11.0002

Received: 08 May, 2020

Accepted: 11 May, 2020

Published: 28 Aug., 2020

Copyright $\odot 2020$ Qian et al., This article was first published in Molecular Plant Breeding in Chinese, and here was authorized to translate and publish the paper in English under the terms of Creative Commons Attribution License, which permits unrestricted use, distribution, and reproduction in any medium, provided the original work is properly cited.

Preferred citation for this article:

Qian J.Y., Liu F., Qu C., and Wang Y., 2020, Research progress on cloning and mechanism of rice lesion mimic genes, Rice Genomics and Genetics, 11(2): 1-8 (doi: $10.5376 /$ rgg.2020.11.0002)

\begin{abstract}
The formation of rice lesion mimic was affected by gene mutation, metabolic disorder, accumulation of active oxygen, hormone imbalance, blocked ion channels, out of control programmed cell death process, abiotic stress and so on. The process of disease was usually accompanied by the improvement of plant resistance, and the expression of defense system related genes increases. At present, the study of disease-like mutants mainly focused on the mapping, cloning and functional analysis of mutant genes. The mechanism of rice lesion mimic mutants was reviewed, especially the location, coding and function of the cloned disease like genes In this paper. The mechanism of programmed cell death in rice disease like cells was summarized, and the prospect of disease like mutants and rice breeding practice was put forward. It was of great significance to further analyze the regulatory mechanism of defense response and breeding application of rice lesion mimic mutant gene.
\end{abstract}

Keywords Rice; Lesion mimic; Gene cloning; Mechanism

Rice (Oryza.sativa L.) is one of the main grain crops and a series of heritable changes will be found during its production, while some can be visible to the naked eye. Rice lesion mimic (RLM) refer to the necrotic spot spontaneously formed with the development of rice. It could be divided into two types, one is diffuse, which is mainly produced by the inhibition of programmed cell death (PCD). A point on its leaves is stimulated by external factors, resulting in cell necrosis and progressive spread around, and finally spread to the whole leaf or even the whole plant, that is, uncontrolled spread of disease spots. Another is initial, these mutants are mainly produced by the excitation of programmed cell death, which occurs randomly in many parts of the leaf without external excitation, thus forming spontaneously, but not spreading (Hoisington et al., 1982; Lorrain et al., 2003). Therefore, it is of great significance to study the disease resistance mechanism of rice mutant, and breeding application.

\section{Source and Performance Characteristics of Rice Lesion Mimic Mutants}

The lesion mimic mutant (LMM) was first found in maize (Lu et al., 2012). In subsequent decades, the first rice lesion mimic mutant -sekiguchi lesion was found, which is a recessive mutant produced by natural mutation (Imaoka et al., 2008). Rice lesion mimic mutant is mainly produced by natural and artificial mutation. Natural mutation is mainly induced by environmental factors such as temperature, humidity, germs or radiation. Most of these are meaningless mutations that tend to be eliminated, and is not easy to happen (Xiao et al., 2017). Artificial mutagenesis is formed by physical, chemical and biological methods. Physical mutagenesis mainly induces plant seeds with the help of high energy radiation such as $\mathrm{X}$ and $\gamma$ ray, which leads to the mutation of chromosome structure of plant cells, makes the genome sequence change accordingly. Chemical mutagenesis is induced by some alkylating agents, base nucleic acid analogues and other chemical mutagens. The principle of action is similar to physical mutagenesis. Biological mutagenesis is to use genetic engineering techniques such as T-DNA insertion or transposon tag to mutagenesis, so that the plant genome can produce site-directed mutagenesis or frameshift mutagenesis. The phenotype of some mutants appears at the seedling stage, while the phenotype of some mutants does not appear on the plant until late growth or heading stage (Liu et al., 2004; Wang et al., 2004). 
The production rice lesion mimic will also be affected by temperature, light and other ecological factors. Arase et al. (2000) found that the phenotypic characteristics of rice lesion mimic mutant $m 1009$ were affected by temperature. When the temperature was lower than $20^{\circ} \mathrm{C}$, the lesion mimic mutant phenotype appeared, but no obvious characteristics were found at higher than $25^{\circ} \mathrm{C}$. Yamanouchi et al. (2000) found that the production of spl7 mutant is related to ultraviolet light and high temperature conditions. Wu et al. (2008) found that after the mutant spl19 appeared, the leaf curl, dry, narrow and seed setting rate decreased and other phenomena also appeared.

\section{Mutation Mechanism of RLM \\ 2.1 Genic mutation}

The mutation or abnormal expression of disease resistance and stress resistance related genes in rice may lead to the deviation of signal transmission pathway, which may lead to the passive occurrence or elimination of stress response, resulting in programmed cell death, and then produce rice lesion mimic mutant. Yamanouchi et al. (2002) found that the SPl7 gene was the first lesion mimic mutant gene found in rice, which was obtained by $\gamma$ radiation mutagenesis of japonica rice varieties. Its traits were controlled by a single invisible gene and located on chromosome 5. At low temperature in the field, the mutant spl7 appeared from tillering stage to maturity stage, but under sunlight condition, no mutant appeared at high or low temperature. This indicates that the mutant phenotype is affected by temperature and light. Spl7 gene coding, a transcription factor regulated by light and temperature, changes the structure of the protein so that it cannot be expressed normally, and then loses its function, which eventually leads to the formation of lesion mimic.

\subsection{Metabolic disturbance}

The process of plant growth and metabolism is regulated by a variety of enzymes and proteins. Decreased activity or loss of function of these enzymes or proteins will cause metabolic disorders in plants, leading to lesion mimic mutant. At the same time, in the process of chlorophyll synthesis, the expression of pigmentogen deaminase and other genes related to the synthesis pathway was inhibited, which also caused the lesion mimic mutant. Sun et al. (2011) found that found that the mutation of chlorophyll synthesis related genes in rice resulted in the decrease of fecal porphyrinogen III oxidase activity, accumulation of fecal porphyrinogen III in rice plants, and disturbance of the metabolism of chlorophyll and heme. Sakuraba et al. (2013) showed that the rice lesion mimic mutant $f g l$ because of the frameshift mutation in the second exon of the gene associated with the original chlorate redox enzyme coding, the synthesis of the original chlorophyll ester redox enzyme B was terminated in advance, which in turn led to the disorder of chlorophyll metabolism, and the rice plant leaves appeared lesion mimic.

\subsection{Reactive oxygen species accumulation}

The production of many lesion mimic mutants is closely related to the accumulation of reactive oxygen species in plants. Reactive oxygen species (ROS) is a kind of metabolites with high oxidation activity and certain toxicity. Reactive oxygen species usually maintain a low level of dynamic balance in plants. Once the accumulation of reactive oxygen species (ROS) in plants is large, it will cause damage and accelerate the process of plant senescence. Lin et al. (2012) found that the main reason for the noel to produce lesion mimic phenotype was the significant increase in hydrogen peroxide content in plants, which in turn activated nitrate reductase, resulting in a large accumulation of nitric oxide in rice.

\subsection{Hormonal imbalance}

As hormone signaling molecules, ethylene, salicylic acid and jasmonic acid play an important role in the signaling process in plants. And metabolic disorders of these hormones may lead to the production of lesion mimic. Jiang et al. (2009) found that the increase of endogenous salicylic acid level of ssil2 induced a significant increase in the expression of key factors regulating rice resistance WRKY45 resulting in lesion mimic mutant. 
Rice Genomics and Genetics 2020, Vol.11, No.2, 1-8

\subsection{Lonic channel blocked}

In plant cells, cytoplasmic ions play an important role in the defense system in plants. Ion channels associated with abnormal gene expression, which may cause metabolic disorders and then cause lesion. Balague et al. (2003) found that HLM1 genes play an important role in cyclic nucleotide-gated channels, which is activated by cGMP and cAMP to allow $\mathrm{K}^{+} 、 \mathrm{Na}^{+}$to pass through, thus $h l m l$ mutants to produce lesion mimic when they exhibit abnormal disease-resistant allergic reactions. $\mathrm{Ca}^{2+}$ signaling also plays a very important role in the immune regulation in plants.

\subsection{Rice PCD process lost control}

PCD is a very critical process of rice lesion mimic. Zeng et al. (2004) found that mutant spll1 is able to encode U-Box/ARM proteins with E3 ubiquitin ligase functions. U-Box/ARM proteins negatively regulate the defense response and cell death process in rice. Spl11 interact with SPIN1 and RBS1 proteins, leading to early termination of translation of spl11 proteins, suggesting that spl11 proteins may negatively regulate plant PCD and defense responses through the ubiquitin pathway. Liu et al. (2017) found that rice lesion mimic mutant $1 \mathrm{~m}-\mathrm{ZH}$ phenotypic characteristics are caused by OsCUL3a dysfunction. OsCUL3a is able to interact with OsNPR1 in vivo and mediate its $26 \mathrm{~S}$ proteasome degradation process, which can negatively regulate rice PCD process by targeting degradation.

\subsection{Abiotic stress}

When rice is stressed by abiotic factors such as light and temperature, the plant will make a series of immune responses in order to adapt to the external environment. In this process, PCD, ROS and immune defense system will be turned on, which will lead to the occurrence of lesion mimic. The mutant lmps 1 was affected by light. Under the condition of lighting, the spots of the mutant were not appeared, but after the restoration of light, the lesion mimic phenotype appeared again, and its photosynthetic pigment content was significantly reduced (Xia et al., 2019). Wang et al. (2004) found that high temperature would lead to a decrease in the number of lesion mimic mutants. However, at the later stage of rice growth, the inhibitory effect of temperature on the phenotype of disease-like spot was not obvious.

\section{Cloning of Rice Lesion Mimic Genes}

Through long periods of natural selection, rice has evolved a sophisticated immune defense system against pathogens from the outside world. Among the lesion mimic genes that have been mapped and cloned, many genes show resistance to rice diseases, and this resistance is usually associated with disease-like phenotypes. By analyzing the function of 20 lesion mimic mutation genes, it was found that they almost participated in different signal pathways and defense pathways (Table 1). The cloning and function of different types of lesion mimic mutations were summarized.

spll1 mutant was obtained from indica rice varieties induced by EMS. It was controlled by a single invisible gene and located on chromosome 12 of rice. The leaves of spll1 mutant showed iron rust spots from late tillering stage to mature stage, and it was found that the resistance of spl11 mutants to rice blast and bacterial blight was higher than that of wild type (Zeng et al., 2004). SPL11 gene encodes an E3 ubiquitin ligase. Gene sequence analysis showed that the mutation site resulted in the production of a stop codon, which could not form a complete transcription product, and eventually led to the formation of leaf lesions.

SPL18 gene is the first dominant lesion mimic gene to be discovered. It is obtained by inserting T-DNA into the mutant Nipponbare (Oryza sativa L. ssp japonica), and it is located on chromosome 12 of rice (Mori et al., 2007). Compared with the wild type, the gene expression was mainly concentrated in the spike and leaf sheath, and the leaf expression was low, which increased the number of lesions and enhanced the resistance to rice blast Spl18 gene encodes an acyltransferase, the expression of PR1 and PBZ1 is increased, and the content of phytoalexin is also increased, which is reflected in the increase of the content of Sakura and Momilactone A. 
Rice Genomics and Genetics 2020, Vol.11, No.2, 1-8

Table 1 Cloned of rice lesion mimic genes

\begin{tabular}{|c|c|c|c|c|}
\hline Gene name & Chromosome & Gene encoding & Gene function & Reference \\
\hline OsNPR1 & 1 & $\begin{array}{l}\text { Transcription } \\
\text { coactivator }\end{array}$ & $\begin{array}{l}\text { Regulation of jasmonate and salicylic acid } \\
\text { resistance pathway }\end{array}$ & Yuan et al., 2007 \\
\hline OsSSI2 & 1 & Fatty acid desaturase & $\begin{array}{l}\text { Participate in the negative regulation of rice } \\
\text { disease resistance pathway mediated by salicylic } \\
\text { acid }\end{array}$ & Jiang et al., 2009 \\
\hline SPL28 & 1 & $\begin{array}{l}\text { Adaptor protein } \\
\text { complex }\end{array}$ & $\begin{array}{l}\text { Involved in the regulation of vesicle transport in } \\
\text { cytoplasmic matrix }\end{array}$ & Qiao et al., 2010 \\
\hline OsCUL3a & 2 & $\begin{array}{l}\text { Cullin like ubiquitin } \\
\text { ligase }\end{array}$ & $\begin{array}{l}\text { Negative regulation of cell death and defense } \\
\text { stress in Rice by targeted degradation of OsNPR1 }\end{array}$ & Liu et al., 2017 \\
\hline GF14e & 2 & 14-3-3 protein & Regulation of plant immune stress & Manosalva et al., 2011 \\
\hline OsHPL3 & 2 & Lipohydroperoxidase & Participate in lipid and oxygen metabolism & Tong et al., 2012 \\
\hline OsLMS & 2 & RNA binding protein & $\begin{array}{l}\text { Mediated resistance response of Magnaporthe } \\
\text { grisea }\end{array}$ & Undan et al.,2012 \\
\hline CEA62 & 2 & Allene oxide synthase & Participate in mediating plant cell defense response & Liu et al., 2012 \\
\hline OsACDR1 & 3 & RAF like mpkk kinase & $\begin{array}{l}\text { Participate in negative regulation of rice disease } \\
\text { resistance pathway and positive regulation of } \\
\text { ethylene synthesis }\end{array}$ & Kim et al., 2009 \\
\hline RLIN1 & 4 & $\begin{array}{l}\text { Fecal porphyrinogen III } \\
\text { oxidase }\end{array}$ & $\begin{array}{l}\text { Participate in the metabolism of tetrapyrrole in } \\
\text { Rice }\end{array}$ & Sun et al., 2011 \\
\hline SPl7 & 5 & $\begin{array}{l}\text { heat shock } \\
\text { transcriptional factor }\end{array}$ & Negative regulation of apoptosis by heat shock & Yamanouchi et al., 2002 \\
\hline OsPtila & 5 & $\begin{array}{l}\text { Receptor protein } \\
\text { kinases }\end{array}$ & $\begin{array}{l}\text { RAR1 dependent negative regulation of rice } \\
\text { immune stress }\end{array}$ & Takahashi et al., 2007 \\
\hline SPL5 & 7 & Sf3b3 splicing factor & $\begin{array}{l}\text { Regulation of plant defense response and cell } \\
\text { death by RNA splicing }\end{array}$ & Chen et al., 2012 \\
\hline OsLSD1 & 8 & Zinc finger protein & Participate in the negative regulation of apoptosis & Wang et al., 2005 \\
\hline SPL29 & 8 & UAP1 gene & Participate in carbohydrate metabolism & Wang et al., 2015 \\
\hline$F G L$ & 10 & OsPORB protein & $\begin{array}{l}\text { Participate in chlorophyll or other cytochrome } \\
\text { synthesis }\end{array}$ & Sakuraba et al., 2013 \\
\hline NLS1 & 11 & $\begin{array}{l}\text { CC-NB-LRR type } \\
\text { protein }\end{array}$ & $\begin{array}{l}\text { Participate in the signal transduction of plant } \\
\text { immune response and defense response to } \\
\text { pathogens }\end{array}$ & Tang et al., 2011 \\
\hline OsSL & 12 & Cyp71p1 protein & Participate in the biosynthesis of serotonin in Rice & Fujiwara et al., 2010 \\
\hline SPL11 & 12 & $\begin{array}{l}\text { U-box E3 ubiquitin } \\
\text { ligase }\end{array}$ & Participate in the plant apoptosis defense & Zeng et al., 2004 \\
\hline SPL18 & 12 & Acyltransferase & Positive regulation of PCD and defense response & Mori et al., 2007 \\
\hline
\end{tabular}

spl5 mutant was obtained from non-glutinous rice induced by $\gamma$-ray irradiation and located on chromosome 7 . The mutant appeared reddish brown or tan spots $15 \sim 20 \mathrm{~d}$ after sowing to heading stage, and the number of spots increased with the growth of the plant (Chen et al., 2012). Spl5 gene encodes a SF3B3, which negatively regulates defense stress response and cell death by regulating RNA splicing.

OSLSD1 gene, a rice lesion mimic mutation controlled by endogenous signaling pathway, is located on chromosome 8 (Wang et al., 2005). Oslsd1 mutation will cause HR lesion. And OsLSD1 gene overexpression will accelerate plant regeneration, increase the content of chlorophyll B, improve the ability of photosynthesis, and thus promote growth, differentiation, and regeneration. OSLSDI gene and Arabidopsis thaliana LSD gene encode proteins containing three zinc finger domains and are expressed in the nucleus.

OSPTIIA gene is a recessive gene located on chromosome 6, which is obtained by inserting the retrotransposon Tos17 (Tos17 triggered mutational) into the genome of Nipponbare (Takahashi al., 2007). About 30 days after 
ttm1 mutants were planted in the field, fuzzy brown spots spontaneously appeared on both sides of the leaves. The resistance of Xanthomonas oryzae and Magnaporthe grisea increased after the appearance of the lesion mimic. OSPTIIA is a plasma membrane protein kinase-related gene. The expression of resistance and the signal transduction of defense response play a negative regulatory role.

A mutation caused by transposon insertion of the hpl3-1 mutant on chromosome 2. The seedlings of hpl3-1 mutant began to appear lesion in 2 weeks. With the growth of the plant, the lesion extended to the whole leaf until the leaf necrosis. In addition, the mutant showed dwarfing, which affected the main agronomic shape (Tong et al., 2012). OSHPL3 gene encodes fatty acid hydroperoxide lyase, which affects lipoxygenase metabolism. The mutation caused damage to HPL, accumulation of SA, and activation of plant stress defense response.

\section{Resistance Mechanism of Rice Lesion Mimic Mutants}

Many lesion mimic mutants would changes in physiological indicators at the cellular level, such as the initiation of anaphylaxis in the plant, thereby showing increased resistance in the plant. A large number of studies also showed that most of the rice lesion mimic mutants were resistant to Xanthomonas oryzae or Magnaporthe grisea (Chen et al., 2011). Luo et al. (2012) also confirmed that AtNPR1 could enhance the resistance to Magnaporthe grisea and reduce yield loss. During the process from the emergence of lesion mimic to leaf wilt and necrosis, intermediate metabolites of reactive oxygen species accumulate rapidly, which directly leads to allergic reactions and stress reactions that kill pathogenic bacteria (Wang et al., 2006). Takahashi et al. (1999) showed that during the onset of mutants $c d r 1 \sim 2$ and $c d r 3$, in addition to the accumulation of intermediate metabolites of reactive oxygen species, a large amount of callose and phenolic substances were also accumulated in cells, and the production of these substances could enhance the defense system of plant. Summarized the resistance mechanism of some rice lesion mimic mutants (Figure 1), it was found that ethylene, green leaf volatiles, jasmonic acid and salicylic acid were also involved in plant resistance and stress response during the PCD process of rice. Reactive oxygen species (ROS) and their intermediate metabolites are the first type of signal molecules. Most of them cause the production rate of reactive oxygen species to exceed the decomposition rate, resulting in the accumulation of reactive oxygen species, thus activating the intracellular antioxidant enzyme system and maintaining the balance system of intracellular reactive oxygen species. When the reactive oxygen species reached a certain level, it would activate the programmed cell death pathway in the cells, and finally the lesion mimic appeared on the leaves.

\section{Progress}

The formation of rice lesion mimic is affected by many factors, and rice resistance is also related to the lesion mimic process. The lesion mimic mutants usually induce immune response in the process of lesion, and induce defense system and show certain resistance to rice diseases. Meanwhile, the plant height, effective panicle number, grain number per spike, seed setting rate and other agronomic traits were also affected. Therefore, the cloning and functional analysis of rice lesion mimic mutation genes are becoming more and more important, and the molecular regulation mechanism of rice lesion mimic mutation needs to be further studied.

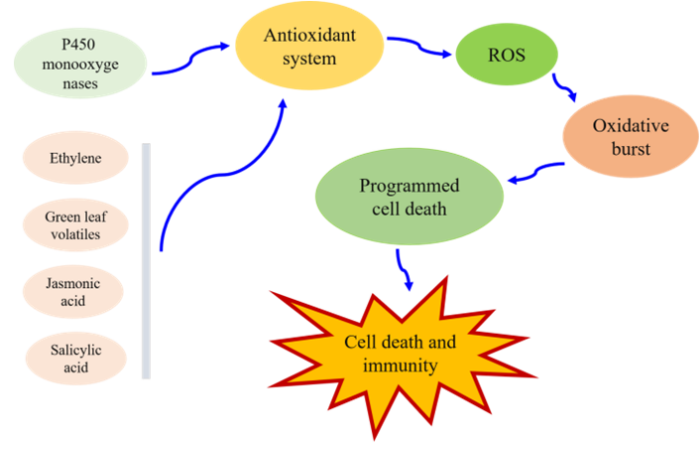

Figure 1 Mechanism of PCD in some rice lesion mimic mutation 
Rice Genomics and Genetics 2020, Vol.11, No.2, 1-8

At present, most of the cloned lesion mimics mutation genes showed good resistance to Xanthomonas oryzae and Magnaporthe grisea. Therefore, how to use this type of gene, combined with the major functional genes of Xanthomonas oryzae and Magnaporthe grisea, to improve yield and quality, and to play a synergistic role in resistance, will be worthy of further research. Especially for Xanthomonas oryzae resistance breeding, it is urgent to improve the horizontal resistance, aggregate different main effect functional genes, and enhance the broad-spectrum and long-lasting disease resistance in rice breeding and production.

\section{Authors' contributions}

QJY completed data collection and analysis, drafted the manuscript, and proofread. LF participated in the design and revision of the study. QC conceived and directed of this study, helped to draft and revises the manuscript. All authors read and approved the final manuscript.

\section{Acknowledgements}

This study was supported by the National Natural Science Foundation of China (31971923, 31301650), Scientific Research Fund of Hunan Provincial Education Department (19A220), Talent Fund of Hunan Agricultural University (YXQN2018-10), and Postgraduates Scientific Research and Innovation Project of Hunan Province (CX2017B377).

\section{References}

Arase S., Zhao C.M., Akimitsu K., Yamamoto M., and Ichii M., 2000, A recessive lesion mimic mutant of rice with elevated resistance to fungal pathogens, Journal of General Plant Pathology, 66(2): 109-116 https://doi.org/10.1007/PL00012930

Balague C., Lin B.Q., Alcon C., Flottes G., Malmstrom S., Kohler C., Neuhaus G., Pelletier G., Gaymard F., and Roby D., 2003, HLM1, An essential signaling component in the hypersensitive response, is a member of the cyclic nucleotide-gated channel ion channel family, Plant Cell, 15(2): 365-379 https://doi.org/10.1105/tpc.006999 PMid:12566578 PMCid:PMC141207

Chen X.F., Hao L., Pan J.W., Zheng X.X., Jiang G.H., Jin Y., Gu Z.M., Qian Q., Zhai W.X., and Ma B.J., 2012, SPL5, a cell death and defense-related gene, encodes a putative splicing factor 3b subunit 3 (SF3b3) in rice, Molecular Breeding, 30(2): 939-949 https://doi.org/10.1007/s11032-011-9677-4

Chen X.F., Jin Y., and Ma B.J., 2011, Progress on the studies of rice lesion mimics and their resistant mechanism to the pathogens, Zhiwu Bingli Xuebao (Acta Phytopathologica Sinica), 41(1): 1-9

Fujiwara T., Maisonneuve S., Isshiki M., Mizutani M., Chen L.T., Wong H.L., Kawasaki T., and Shimamoto K., 2010, Sekiguchi lesion gene encodes a cytochrome P450 monooxygenase that catalyzes conversion of tryptamine to serotonin in Rice, Journal of Biological Chemistry, 285(15): 11308-11313 https://doi.org/10.1074/ibc.M109.091371 PMid:20150424 PMCid:PMC2857009

Hoisington D.A., Neuffer M.G., and Walbot V., 1982, Disease lesion mimics in maize: I. Effect of genetic background, temperature, developmental age, and wounding on necrotic spot formation with Les1, Developmental Biology, 93(2): 381-388 https://doi.org/10.1016/0012-1606(82)90125-7

Imaoka A., Ueno M., Kihara J., Kadowaki M., and Arase S., 2008, Effect of a Photo: ynthetic Inhibitor on Tryptamine Pathway-mediated Sekiguchi Lesion Formation in Lesion Mimic Mutant of Rice Infected with Magnaporthe grisea, Journal of Phytopathology, 156(9): 522-529 https://doi.org/10.1111/j.1439-0434.2008.01405.x

Jiang C.J., Shimono M., Maeda S., Inoue H., Morl M., Hasegawa M., Sugano S., and Takatsujl H., 2009, Suppression of the rice fatty-acid desaturase gene OsSSI2 enhances resistance to blast and leaf blight diseases in rice, Mol Plant Microbe Interact, 22(7): 820-829 https://doi.org/10.1094/MPMI-22-7-0820 PMid: 19522564

Kim J.A., Cho K., Singh R., Jung Y.H., Jeong S.H., and Kim S.H., 2009, Rice OsACDR1 (Oryza sativa accelerated cell death and resistance 1) is a potential positive regulator of fungal disease resistance, Moleculer Cells, 28(5): 431-439 https://doi.org/10.1007/s10059-009-0161-5 PMid: 19904499

Lin A., Wang Y., Tang J., Xue P., Li C., Liu L., Hu B., Yang F., J.Loake G., and Chu C., 2012, Nitric oxide and protein s-nitrosylation are integral to hydrogen peroxide-induced leaf cell death in rice, Plant Physiology, 158(1): 451-464 https://doi.org/10.1104/pp.111.184531 PMid:22106097 PMCid:PMC3252116

Liu G., Wang L., Zhou Z., Leung H., Wang G.L., and He C., 2004, Physical mapping of a rice lesion mimic gene, Spl1, to a 70-kb segment of rice chromosome 12, Molecular Genetics and Genomics, 272(1): 108 https://doi.org/10.1007/s00438-004-1040-6 PMid: 15258851 
Rice Genomics and Genetics 2020, Vol.11, No.2, 1-8

Liu Q., Ning Y., Zhang Y., Yu N., Zhao C., Zhan X., Wu W., Chen D., Wei X., and Wang G.L., 2017, OsCUL3a negatively regulates cell death and immunity by degrading OsNPR1 in Rice, Plant Cell, 29(2): 345-359

https://doi.org/10.1105/tpc.16.00650

PMid:28100706 PMCid:PMC5354189

Liu X.Q., Li F., Tang J.Y., Wang W.H., Zhang F.X., Wang G.D., Chu J.F., Yan C.Y., Wang T.Q., Chu C.C, and Li C.Y., 2012, Activation of the Jasmonic Acid Pathway by Depletion of the Hydroperoxide Lyase OsHPL3 Reveals Crosstalk between the HPL and AOS Branches of the Oxylipin Pathway in Rice, Plos One, 7(11): e50089

https://doi.org/10.1371/journal.pone.0050089

PMid:23209649 PMCid:PMC3510209

Lorrain S., Vailleau F., Balaque C., and Roby D., 2003, Lesion mimic mutants: keys for deciphering cell death and defense pathways in plants, Trends in Plant Science, 8(6): 263-271 https://doi.org/10.1016/S1360-1385(03)00108-0

Luo X.M., Luo T.P., Nong Q.D., Feng J.X., Li R.B., and Duan C,J., 2012, Disease resistance and agronomic traits in t3 generation of transgenic rice cultivar gui99 with NPR1 gene from a ra idopsis thaliana, Jiyin Zuxue Yuying Yongsheng Wuxue (Genomics and Applied Biology), $31(2)$ : 167-172

Lu X.M., Hu X.J., Zhao Y.Z., Song W.B., Zhang M., Chen Z.L., Chen W., Dong Y.B., Wang Z.H., and Lai J.S., 2012, Map-based cloning of zb7 encoding an IPP and DMAPP synthase in the MEP pathway of maize, Mol Plant, 5(5): 1100-1112

https://doi.org/10.1093/mp/sss038

PMid:22498772

Manosalva P.M., Bruce M., and Leach J.E., 2011, Rice 14-3-3 protein (GF14e) negatively affects cell death and disease resistance, Plant Journal, 68(5): 777-787

https://doi.org/10.1111/j.1365-313X.2011.04728.x

PMid:21793954

Mori M., Tomita C., Sugimoto K., Hasegawa M., Hayashi N., Dubouzet J.G., Ochiai H., Sekimoto H., Hirochika H., and Kikuchi S., 2007, Isolation and molecular characterization of a Spotted leaf 18 mutant by modified activation-tagging in rice, Plant Molecular Biology, 63(6): 847-860

https://doi.org/10.1007/s11103-006-9130-y PMid: 17273822

Qiao Y.L., Wenzhu J., Joohyun L., Bongsoo P., Min-Seon C., Rihua P., Mi-Ok W., Jae-Hwan R., Longzhi H., and Nam-Chon P., 2010 , SPL28 encodes a clathrin-associated adaptor protein complex 1 medium subunit micro 1 (AP1M1) and is responsible for spotted leaf and early senescence in rice (Oryza sativa), New Phytol, 185(1): 258-274

https://doi.org/10.1111/j.1469-8137.2009.03047.x PMid: 19825016

Sakuraba Y., Rahman M.L., Cho S.H., Kim Y.S., Koh H.J., Yoo S.C., and Paek N.C., 2013, The rice faded green leaf locus encodes protochlorophyllide oxidoreductase B and is essential for chlorophyll synthesis under high light conditions, Plant Journal, 74(1): 122-133 https://doi.org/10.1111/tpj.12110 PMid:23289852

Shen X.L., Liu H.B., Yuan B., Li X.H., Xu C.G and Wang S.P., 2011, OsEDR1 negatively regulates rice bacterial resistance via activation of ethylene biosynthesis, Plant Cell \& Environment, 34(2): 179-191

https://doi.org/10.1111/j.1365-3040.2010.02219.x

PMid:20807375

Sun C.H., Liu L.C., Tang J.Y., Lin A., Zhang F.T., Fang J., Zhang G.F., and Chu C.C., 2011, RLIN1, encoding a putative coproporphyrinogen III oxidase, is involved in lesion initiation in rice, Journal of Genetics and Genomics, 38(1): 29-37

https://doi.org/10.1016/j.jcg.2010.12.001 PMid:21338950

Takahashi A., Agrawal G.K., Yamazaki M., Onosato K., Miyao A., Kawasaki T., Shimamoto K., and Hirochika, H., 2007, Rice Ptila negatively regulates RAR1-dependent defense responses, Plant Cell, 19(9): 2940-2951

https://doi.org/10.1105/tpc.106.047142

PMid: 17890377 PMCid:PMC2048693

Takahashi A., Kawasaki T., Henmi K., and Shii K.,1999, Lesion mimic mutants of rice with alterationsin early signaling events of defense, Plant Journal, 17(5): 535-545

https://doi.org/10.1046/j.1365-313X.1999.00405.x

PMid: 10205906

Tang J., Zhu X., Wang Y., Liu L., Xu B., L F., Fang J., and Chu C. 2011, Semi-dominant mutations in the CC-NB-LRR-type R gene NLS1 lead to constitutive activation of defense responses in rice, Plant Journal, 66 (6): 996-1007 https://doi.org/10.1111/j.1365-313X.2011.04557.x

PMid:21418352 
Rice Genomics and Genetics 2020, Vol.11, No.2, 1-8

Tong X.H., Qi J.F., Zhu X.D., Mao B.Z., Zeng L.J., Wang B.H., Li Q., Zhou G.X., Xu X.J., Lou Y.G., and He Z.H., 2012, The rice hydroperoxide 1yase OsHPL3 functions in defense responses by modulating theoxylipin pathway, Plant Journal, 71(5): 763-775 https://doi.org/10.1111/j.1365-313X.2012.05027.x PMid:22519706

Undan J.R., Tamiru M., Abe A., Yoshida K., Kosugi S., Takagi H., Yoshida K., Kanzaki H., Saitoh H., and Fekih R., 2012, Mutation in OsLMS, a gene encoding a protein with two double-stranded RNA binding motifs causes lesion mimic phenotype and early senescence in rice (Oryza sativa L.), Genes Genet Syst, 87(3): 169-179

https://doi.org/10.1266/ggs.87.169 PMid:22976392

Wang J.J., Zhu X.D., Wang L.Y., Zhang L.H., Xue Q.Z., and He Z.H., 2004, Physiological and genetic analysis of lesion resembling disease mutants (lrd) of oryza sativa, Zhiwu Shengli Yufenzi Shengwuxue Xuebao (Journal of Plant Physiology and Molecular Biology), 30(3): $331-338$

Wang L., Pei Z., Tian Y., and He C., 2005, OsLSD1 a rice zinc finger protein regulates programmed cell death and callus differentiation, Molecular Plant-microbe Interactions, 18(5): 375-384

https://doi.org/10.1094/MPMI-18-0375

PMid: 15915636

Wang Z.H., Wang Y., Hong X., Hu D.H., Liu C.X., Yang J., Li Y., Huang Y.Q., Feng Y. Q., Gong H.Y., Li Y., Fang G., Tang H.R., and Li Y.S., 2015, Functional inactivation of UDP-N-acetylglucosamine pyrophosphorylase 1 (UAP1) induces early leaf senescence and defence responses in rice, Journal of Experimental Botany, 66(3): 973-987

https://doi.org/10.1093/jxb/eru456 PMid:25399020 PMCid:PMC4321554

Wang Z.H., and Jia Y.L., 2006, Induction and prelimingagy analysis of a rice lesion miminc mutant $l m m 1$, Henogxue Bao (Journal of Nuclear Agricultural Sciences), 20(4): 255-258

Wu C., Bordeos A., Madamba M.R.S., Baraoidan M., Ramos M., Wang G.L., Leach J.E., and Leung H., 2008, Rice lesion mimic mutants with enhanced resistance to diseases, Molecular Genetics and Genomics, 279(6): 605-619

https://doi.org/10.1007/s00438-008-0337-2 PMid: 18357468

Xia S.S., Cui Y., Li F.F., Tan J., Xie Y.H., Sang X.C., and Ling Y.H., 2019, Phenotypic characterizing and gene mapping of a lesion mimicand premature senescence 1 (lmps1) mutant in rice (Oryza sativa L.), Zuowu Xuebao (Acta Agronomica Sinica), 45(01): 46-54 https://doi.org/10.3724/SP.J.1006.2019.82022

Xiao G.Q., Zhang Y.F., Yang B.N., Liu B.C., Zhou J.H., and Zhang H.W., 2017, Research progress of plant lesion mimic mutants, Fenzi Zhiwu Yuzhong (Molecular Plant Breeding), 15(1): 290-299

Yamanouchi U., Yano M., Lin H., Ashikari M., and Yamada K., 2002, A rice spotted leaf gene Spl7 encodes a heat stress transcription factor protein. Proceedings of the National Academy of Sciences, 99(11): 7530-7535

https://doi.org/10.1073/pnas.112209199

PMid:12032317 PMCid:PMC124274

Yuan Y. X., Zhong S. H., Li Q., Zhu Z.R., Lou Y.G., Wang L.Y., Wang J.J., Wang M.Y., Li Q. L., Yang D.L., and He Z.H., 2007, Functional analysis of rice NPR1-like genes reveals that OsNPR1/NH1 is the rice orthologue conferring disease resistance with enhanced herbivore susceptibility, Plant Biotechnology Journal, 5(2): 313-324

https://doi.org/10.1111/j.1467-7652.2007.00243.x

PMid: 17309686

Zeng L.R., Qu S.A., Yang C.W., Baraoidan M., Yan H.Y., and Xie Q., 2004, Spotted leaf11 a negative regulator of plant cell death and defense, encodes a U-box/armadillo repeat protein endowed with E3 ubiquitin ligase activity, Plant Cell, 16(10): 2795-2808

https://doi.org/10.1105/tpc.104.025171

PMid:15377756 PMCid:PMC520972 